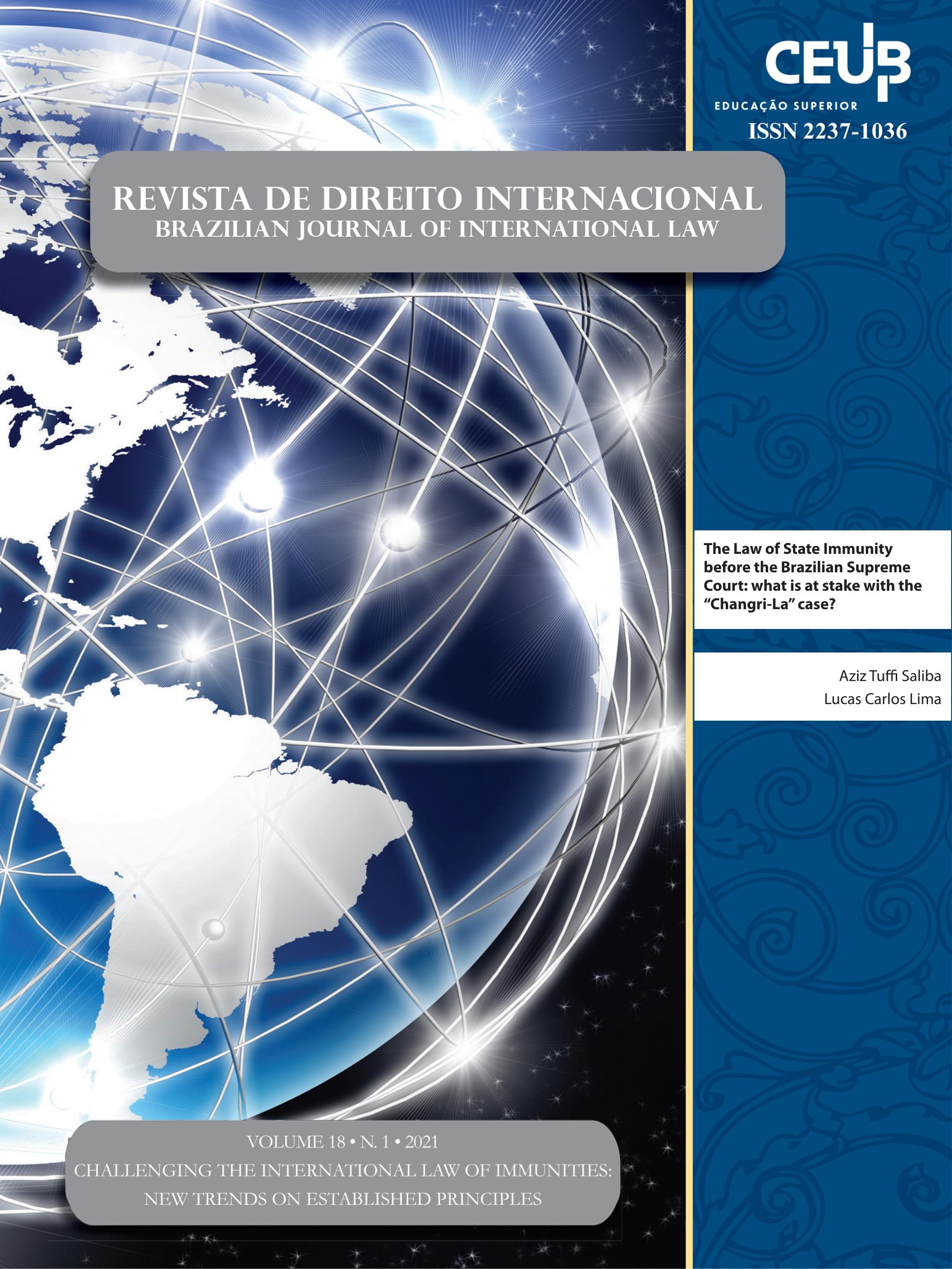


EDITORIAL

Challenging the International Law of Immunities: New Trends on Established Principles? An introduction to the special issue ............................................ 14

Lucas Carlos Lima, Loris Marotti e Paolo Palchetti

CrôniCAS........................................................................................ 17

RESPONSABILIDADE E IMUNIDADE DAS ORgANIZAÇÕES INTERNACIONAIS: PRÁTICA E DESAFIOS ...19 Vinícius Fox Drummond Cançado Trindade

The JURISDiCTIONAL IMMUNITY OF INTERNATIONAL ORgaNiZATIONS BEFORE THE BRAZILIAN SuPREMe Federal Court.

Bárbara Tuyama Sollero

The Law of State Immunity before the Brazilian Supreme Court: what is at stake WITH THE "ChANGRI-LA" CASE?

Aziz Tuffi Saliba e Lucas Carlos Lima

\section{Dossiê: Challenging the International Law of Immunities: New Trends} on Established Principles?

State Immunity and the Rights of Employees: Lights and Shadows of the Strasbourg COURT's JURISPRUdENCE .61

Pierfrancesco Rossi

A human Rights-BASEd CHALlENGE: THE KEY TO UNLOCK THE UN'S IMMUNiTY PROBLEM?...79 Héloïse Guichardaz

IMMUNITIES OF STATE OFFICIALS AND THE "FUNDAMENTALLY DIFFERENT NATURE" OF INTERNATIONAL COURTS: THE APPEALS CHAMBER DECISION IN THE JORDAN REFERRAL RE AL BASHIR ...97 Rita Guerreiro Teixeira e Hannes Verheyden 
IMUNIDADE DE JURISDIÇÃo dOS EsTADOS: O CAMINHO PARA A RELATIVIZAÇÃo

Vinícius Assis da Silveira, Luiz Felipe Costa Santana e Valesca Raizer Borges Moschen

The IMmUNity OF INTERNATIONAL ORganizations IN LABOUR DispUTES. DeVElopments BEFORE INTERNATIONAL TRIBUNALS, NATIONAL COURTS AND THE COLOMBIAN JURISDICTION ..... 137 Walter Arévalo-Ramirez e Ricardo Abello-Galvis

Imunidade de Jurisdição dos Estados E Poder Executivo brasileiro: os Pareceres dos CONSULTORES JURÍDICOS DO ITAMARATY

George Rodrigo Bandeira Galindo

Artigos SOBRe outros temas

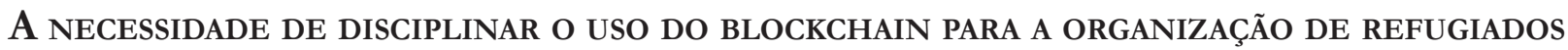
PELO DIREITO INTERNACIONAL. 195

Agatha Gonçalves Santana, Carla Noura Teixeira e Otavio Noura Teixeira

O TRABALHO INFANTIL DE MIGRANTES E REFUgIADOS VENEZUELANOS NO BRASIL

André Viana Custódio e ohana Cabral

THE NEW BRAZILIAN ANTI-TRAFFICKING LAW: CHALLENGES AND OPPORTUNITIES TO COVER THE NORMATIVE LACK . 243 Waldimeiry Correa da Silva

¿SON PARTE DEL BLOQUE DE CONSTITUCIONALIDAD LOS TRATADOS INTERNACIONALES DE DERECHOS HuMANOS DE LA OEA EN CHILE?: AVANCES EN BASE A LA DOCTRINA, NORMATIVA Y JURISPRUDÊNCIA. 270

Juan Pablo Díaz Fuenzalida

O Tratado de Saint-Germain-En-Laye e os Efeitos do instituto da “opÇão” Sobre a CONDIÇÃO JURÍDICA DOS DESCENDENTES DE CIDADÃOS AUSTRÍACOS TRENTINO-TIROLÊSES ......290 Arno Dal Ri Jr. e Andrey José Taffner Fraga

Control Judicial de la Corte Interamericana de Derechos Humanos y Programas Masivos de Reparaciones: Hacia un Enfoque más Matizado .309 Juan Carlos Ochoa-Sánchez 
JuSTICIABILIDADE DIRETA DOS DIREITOS ECONÔMICOS, SOCIAIS, CULTURAIS E AMBIENTAIS NA

Corte Interamericana DE Direitos Humanos..........................................................334

Augusto Antônio Fontanive Leal e Guilherme Massaú

How the indigenous case of Xukuru before the Inter-American Court of Human RiGHTS CAN INSPIRE DECOLONIAL COMPARATIVE STUDIES ON PROPERTY RIGHTS..........................353

Flavianne Fernanda Bitencourt Nóbrega e Camilla Montanha 


\title{
The Law of State Immunity before the Brazilian Supreme Court: what is at stake with the "Changri-La" case?*
}

\author{
Aziz Tuffi Saliba** \\ Lucas Carlos Lima***
}

It was 1943 when the Changri-La fishing boat and its ten fishermen crew disappeared near Cabo Frio, Rio de Janeiro. But only in 2001 the Tribunal Maritimo da Marinha do Brasil recognized that the vessel had been sunk by a German submarine. ${ }^{1}$ The relatives of the victims sought compensation at the Brazilian courts for its material damages and non-pecuniary losses. ${ }^{2}$ However, they stumbled upon a customary norm of Public International Law: the rule prescribing that a State is entitled to immunity in respect of acta jure imperii before the domestic courts of another State. After a long journey within the Brazilian courts, the case reached the Supremo Tribunal Federal (STF) - the Brazilian Supreme Court, which blends functions of constitutional review and court of last appeal - and in March 2021, the trial finally started. In the Extraordinary Appeal with Interlocutory Appeal (ARE) 954858 3 - currently suspended after Justice Alexandre de Moraes' request to see the records -, it is discussed whether human rights violations are an exception to the rule of States' sovereign immunity.

The Brazilian Supreme Court has at least two extreme options before it. The first is to apply customary international law as identified by the International Court of Justice in the Jurisdictional Immunities of the State (Germany v. Italy) and guarantee Germany's immunity from jurisdiction. A second option for STF would be to uphold the right to a fair trial relying on recent foreign judicial decisions that rebuff the rule of immunity in cases of grave violations of human rights. This avenue would open the gate for diplomatic incidents and one should keep in mind the risks that may ensue from the recognition of a broad exception to immunity

* Recebido em 21/07/2021 Aprovado em 21/07/2021

** Aziz Tuffi Saliba is professor of International Law, Faculty of Law, Universidade Federal de Minas Gerais. PhD (Universidade Federal de Minas Gerais), LLM (University of Arizona). E-mail: azizsaliba@ufmg.br

*** Lucas Carlos Lima is professor of International Law, Faculty of Law, Universidade Federal de Minas Gerais. PhD (Università di Macerata), LLM (Universidade Federal de Santa Catarina).

E-mail: lclima@ufmg.br

\footnotetext{
BRAZIL. Tribunal Marítimo. Processo no 812/1943. Acórdão. B/P "CHANGRI-LÁ". Naufrágio de barco de pesca, com a perda total da embarcação e a morte de dez tripulantes: José da Costa Marques, Deocleciano Pereira da Costa, Otávio Vicente Martins, Ildefonso Alves da Silva, Manoel Gonçalves Marques, Manoel Francisco dos Santos Júnior, Otávio Alcântara, Zacarias da Costa Marques, Apúlio Vieira de Aguiar e Joaquim Mata de Navarra. Oficiar à Diretoria de Portos e Costas e ao Serviço de Documentação da Marinha com o teor desta decisão, para as medidas competentes. Ataque pela artilharia do submarino alemão U-199, durante a $2^{\text {a }}$ Guerra Mundial. Judgement of 31 July 2001. Available at: < https://tmjurisprudencia.marinha.mil.br/solr/anuarios/812.pdf>.

2 On the issue, see SALIBA, Aziz Tuffi; MAIA, Tainá. Changri-lá, Antônio Apúlio Aguiar Coutinho and others v The Federal Republic of Germany, Reparation proceedings, Ordinary appeal judgment, No 2008/0042275-3, ILDC 1160 (BR 2008). In: NOLLKAEMPER, André; REINISCH, August. (Org.). Oxford Reports on International Law in Domestic Courts. 2ed.Oxford: Oxford University Press, 2020.

3 In 2017, the Brazilian Supreme Court recognized that the "Changri-La case" had 'general repercussion', a specific admissibility procedure within STF which accredits certain cases, with relevant economic, political, social or legal issues that extend beyond the subjective interests of the case at hand, to be examined by the full court in order to stablish a "thesis" that becomes a precedent (Article 1.035, \ 1, Brazilian Code of Civil Procedure). It is registered as theme No. 944 .
} 
While the case has not yet reached a conclusion, some Justices have already expressed their legal views - their votes, as they are called in the Brazilian Supreme Court - offering potential outcomes for the discussion. ${ }^{4}$ In this essay, we analyze two issues present in some of the votes: absence of proper engagement with international legal arguments, revealing a detachment from international law, and the possible consequences of the thesis proposed by the reporting Justice, Edson Fachin. Our endeavor is both to comment and to explain what is at stake with the Changri-la case.

The reporting Justice issued his vote in the last week of February 2021. To sum up his reasoning, Justice Fachin voted to set aside the jurisdictional immunity of the German State giving priority to the constitutional rule of the "prevalence of human rights". According to the Justice, "because of the constitutional prescription that gives prevalence to human rights as a principle that governs the Brazilian State in its international relations (Article 4, II), [this Court must] make it effective, setting aside the jurisdictional immunity in the case". ${ }^{5}$

The thesis is undoubtedly innovative and has gathered support from Justices Rosa Weber, Carmen Lúcia, and Dias Toffoli, who followed the vote of the reporting Justice without additional commentaries. With this first round of voting, a first position of the STF has started to form, with four out of eleven Justices deciding towards the limitation of the rule of States' sovereign immunity and accepting the jurisdiction of the Brazilian courts over Germany to decide the reparation of human rights violations.

A diverging vote was presented by Justice Gilmar Mendes and followed by Justice Marco Aurélio Mello. In their view, jurisdictional immunity should prevail.

\footnotetext{
${ }^{4}$ According to the current procedure of the STF, case is drawn to one of the 11 Justices, namely, the reporting Justice, which is responsible for writing the leading vote offering a solution to the dispute. Once the leading vote is published, the other Justices may follow the leading vote; they may follow with divergences; they may open a dissent or follow a dissenting vote. The vote which gathers the greater number of supporters constitutes the final Judgement and the winning thesis of the Tribunal. See, in this regard, CHAIB, André Nunes; MENDES, Gilmar Ferreira. Supreme Federal Tribunal of Brazil (Supremo Tribunal Federal). Max Planck Encyclopedia of Comparative Constitutional Law [MPECCoL], 2017.

5 Translation from Portuguese. From the original: "diante da prescrição constitucional que confere prevalência aos direitos humanos como princípio que rege o Estado brasileiro nas suas relações internacionais (Artigo $4^{\circ}, \mathrm{II}$ ), [esta Corte deve] torná-la efetiva, afastando a imunidade de jurisdição no caso".
}

For Justice Gilmar Mendes, the STF should "maintain the integrity of its own jurisprudence, which has maintained absolute immunity in the case of sovereign acts, as in the case under analysis, besides reflecting the majority exegesis of the international community, which could create an international diplomatic incident' ${ }^{67}$

The question is certainly not new in international law $^{8}$ and sparked vast repercussions mostly when, in 2004, the Italian courts repealed Germany's jurisdictional immunity in the Ferrini case, which regarded grave violations of international law by Germany during World War II. ${ }^{9}$ In that instance, the Italian national jud-

6 Translation from Portuguese. From the original: "manter a integridade da nossa jurisprudência, a qual tem mantido a imunidade absoluta em se tratando de atos de império, tal como no caso em análise, além de refletir a exegese majoritária da comunidade internacional, sob pena de criarmos um incidente diplomático internacional"

7 It was only in 1989 that the STF decided that the jurisdictional immunity did not shield States' acts of a private law nature (acta jure gestionis), in the leading case of ACi 9.696, Caso Genny de Oliveira, regarding litigation of labor rights. However, the jurisdictional immunity of acts which are a manifestation of the State's sovereign authority (acta jure imperii) remained absolute. On the issue of the evolving interpretation of jurisdictional immunities in STF's jurisprudence, see: SOARES, Guido Fernando Silva. Órgãos dos Estados nas Relações Internacionais: Formas da Diplomacia e as Imunidades. Rio de Janeiro: Forense, 2001; GARCIA, Márcio; MADRUGA FILHO, Antenor Pereira (coord.). A Imunidade de Jurisdição e o Judiciário Brasileiro. Brasília: CEDI, 2002; MOLL, Leandro de Oliveira. Imunidades Internacionais: Tribunais Nacionais ante a Realidade das Organizações Internacionais. 2. ed. Brasília: FUNAG, 2011; MADRUGA FILHO, Antenor Pereira. A Renúncia à Imunidade de Jurisdição pelo Estado Brasileiro e o Novo Direito da Imunidade de Jurisdição. Rio de Janeiro: Renovar, 2003; TIBURCIO, Carmen. Extensão e Limites da Jurisdição Brasileira: Competência Internacional e Imunidade de Jurisdição. Salvador: JusPODIVM, 2019.

${ }^{8}$ For a general overview, see FOX, Hazel; WEBB, Philippa. The Law of State Immunity. 3. ed. New York: Oxford University Press, 2013; RUY, Tom; ANGELET, Nocolas; FERRO, Luca (eds.). The Cambridge Handbook of Immunities and International Law. Cambridge: Cambridge University Press, 2019; and ALEBEEK, Rosanne van; PAVONI, Riccardo. Immunities of States and their Officials. In: NOLLKAEMPER, André; REINISCH, August; JANIK, Ralph; SIMLINGER, Florentina (eds.). International Law in Domestic Courts: A Casebook. Oxford: Oxford University Press, 2018. p. 100-169.

9 On the issue, see DE SENA, Pasquale; DE VITTOR Francesca. State Immunity and Human Rights: the Italian Supreme Court Decision on the Ferrini Case. European Journal of International Law, v. 16, n. 1, 2005, p. 89-112. MASSIMO, Iovane. The Ferrini Judgment of the Italian Supreme Court: Opening up Domestic Courts to Claims of Repatriation for Victims of Serious Violations of Fundamental Human Rights. Italian Yearbook of International Law, v. 14, 2004, p. 165-194 e BIANCHI, Andrea. Ferrini v. Federal Republic of Germany. The American Journal of International Law, v. 99, n. 1, jan. 2005 , p. 242-248. See also BORNKAMM, Christoph. State Immunity against Claims Arising from War Crimes: The Judgement of the International Court of Justice in Jurisdictional Immunities of the 
ge employed international law as a fundamental part of his argument and found an exception to the customary rule of immunity in the face of serious violations of human rights and humanitarian law.

The dispute reached the United Nations' main judicial body, the International Court of Justice (ICJ), which ruled by a solid majority in the case of Jurisdictional Immunities of the State (Germany v. Italy) that Italian court judgments violated international law. ${ }^{10}$ At the 2012 judgment, the ICJ noted that "under customary international law as it presently stands, a State is not deprived of immunity by reason of the fact that it is accused of serious violations of international human rights law or the international law of armed conflict ${ }^{11}$ But the story did not end there. Two years later, the Constitutional Court of Italy rejected ICJ's decision in the Senteza 238/2014, which, in short, found it impossible not to exert jurisdiction for the acts of a foreign State that consist of war crimes and crimes against humanity. ${ }^{12}$ Notably, the Sentenza 238/2014 is still the subject of diplomatic and legal controversies between both States. ${ }^{13}$

There is no doubt that there is still no consolidated exception in international law to the rule of jurisdictional immunity over sovereign acts and much discussion has taken place in recent times ${ }^{14}$. The emergence of a

State. German Law Journal, v. 13, n. 6, 2012, p. 773-782.

${ }^{10}$ On the judgement, see WUERTH, Ingrid. International Law in Domestic Courts and the Jurisdictional Immunities of the State Case. Melbourne Journal of International Law, v. 13, n. 1, 2012.

11 ICJ. Jurisdictional Immunities of the State (Germany v. Italy: Greece intervening), Judgment, ICJ Reports 2012, para. 91.

12 On the issue, see VOLPE, Valentina; PETERS, Anne; BATTINI, Stefano (eds.), Remedies against Immunity? Springer, 2021, p. 237258 and, particularly in this volume, the contributions of TAMS, Christian J. A Dangerous Last Line of Deference: Or, a Roman Court Goes Lutheran, pp. 237-258 and KUNZ, Rafaella. Teaching the World Court Makes a Bad Case: Revisiting the Relationship Between Domestic Courts and the ICJ, pp. 259-280. See also the debate between WÜRKERT, Felix. No custom restricting state immunity for grave breaches $\square$ well why not?. Völkerrechtsblog, 11 Dec. 2014 and FONTANELLI, Filippo. Damage-assessment on the building of international law. Völkerrechtsblog, 15 Dec. 2014,

${ }_{13}$ On the issue, see Questions of International Law, Colliding Legal Systems or Balancing of Values? International Customary Law on State Immunity vs. Fundamental Constitutional Principles in Italian Constitutional Court Decision no. 238/2014, available at: < http:// www.qil-qdi.org/category/zoom-out/colliding-legal-systemsbalancing-values-international-customary-law-state-immunity-vsfundamental-constitutional-principles-italian-constitutional-courtdecision-no-2382014/>; and PETERS, Anne; VOLPE, Valentina. Introduction: In search for conciliation. VerfBlog, 11 May 2017.

${ }_{14}$ The topic was discussed by both the International Law Commission and the Inter-American Juridical Committee. In relation to new rule of customary international law demands a general practice of States, namely, "sufficiently widespread and representative, as well as consistent". ${ }^{15}$ It is difficult to verify such practice in this topic. The question arises whether Brazil - together with Italy, Greece, and South Korea - is at the forefront of such a practice. In such cases, there is a risk of not clearly distinguishing what constitutes practice and what constitutes a violation: the reaction of States and international bodies, such as the International Court of Justice, are significant in this context to assess an emerging practice.

The reporting Justice's vote does not offer an answer to the lack of a rule in international law that repeals immunity. This seems to be a problem of the reasoning espoused in the vote: the detachment from international law.

Some arguments could more consistently support a thesis in favor of easing immunity within international law itself - as can be seen from Judge Cançado Trindade and Judge Yusuf's dissenting votes in Jurisdictional Immunities. But, in the case under analysis, international law is left out, and the reporting Justice encloses himself in Article 4 of the Brazilian Constitution, a guideline for Brazilian foreign relations. ${ }^{16}$ The solution found by the Justice to avoid the application of the precedent of the ICJ was to resort to Article 59 of the Court's statute, which sets forth that judgments are only binding between the disputing parties. However, dismissing ICJ's decision and argument via Article 59 is a controversial option because it evades the problem. It is true that international judgments only bind the parties in dispute.

the work of the former, it essentially supported the United Nations Convention on the Jurisdictional Immunities of States and Their Property, 2004, not yet in force. Regarding the latter, see LIMA, Lucas Carlos. Regionalism in the codification of international law: the experience of the Inter-American Juridical Committee. In: ANNONI, Alessandra; FORLATI, Serena; SALERNO, Francesco. (org.). La codificazione nell'ordinamento internazionale e dell'Unione europea. Società Italiana di Diritto Internazionale (SIDI). Napoli: Editoriale Scientifica, 2019, p. 393-407.

15 ILC. Draft Conclusions on Identification of Customary International Law, with Commentaries. Yearbook of the International Law Commission, v. II, part 2, 2018. p. 1354.

16 Article 4 of the Brazilian Constitution establishes that "The international relations of the Federative Republic of Brazil are governed by the following principles: I - national independence; II prevalence of human rights; III - self-determination of the peoples; IV - non-intervention; V - equality among the states; VI - defense of peace; VII - peaceful settlement of conflicts; VIII - repudiation of terrorism and racism; IX - cooperation among peoples for the progress of mankind; X - granting of political asylum." 
Nonetheless, the authority of the determination of the law made by the International Court, the principal judicial organ of the United Nations, cannot be selectively overlooked. Although a State could ignore the precedent of the ICJ - something quite reckless in the international legal order - it is difficult to foresee in the reporting justice's vote an address of the rule referred and authoritatively ascertained by the International Court.

If one wants to contribute to the affirmation of a new international rule that creates an exception to the rule of jurisdictional immunity, it must carry out a careful examination of international practice and employ arguments from international law, as the Italian Supreme Court did in the "Ferrini case", when it stated the inexistence of immunity when dealing with serious human rights violations. Otherwise, one should focus exclusively on Brazilian domestic law, not dealing with internationally recognized human rights, but, rather, the right of access to justice. One would then embrace the so-called (and also controversial) doctrine of counter-limits, which states that fundamental values of the national order can limit international rules. ${ }^{17}$ This option opens the way for a potential recognition of the violation of the same rule by Brazil. However, the vote of the reporting Justice seems to be in the middle of these two roads: neither international nor constitutional. Thus, it heightens the possibility of inconsistencies between the international and domestic legal systems.

The concern with the infringement of international obligations emerges in the vote of Justice Gilmar Mendes. His reasoning also seems to mirror the idea that the constitutional principle of separation of powers should prevent the judiciary from acting by reinforcing that "in case of non-compliance with any customary rule, the Federative Republic of Brazil, through its Head of State, must assume, at the international level, numerous consequences, with no attribution of the Judiciary Power in this sense". 18

\footnotetext{
${ }_{17}$ On the issue, see: AMOROSO, Daniele. Chapter 11 - Italy. In: PALOMBINO, Fulvio Maria (ed.). Duelling for Supremacy: International Law vs. National Fundamental Principles. Cambridge: Cambridge University Press, 2019. p. 184-209. See also ARCARI, Maurizio; PALCHETTI, Paolo; TANCREDI, Antonello. Il giudice interno di fronte agli obblighi internazionali. Tra ondate identitarie e risacche di dédoublement fonctionnel. Quaderni costituzionali, p. 217224, Mar. 2020.

18 Translation from Portuguese. From the original: "caso proceda ao descumprimento de qualquer norma consuetudinária, a República Federativa do Brasil, através do seu chefe de Estado, deve assumir, no plano internacional, inúmeras consequências, não existindo qualquer atribuição do Poder Judiciário nesse sentido".
}

The second apparent problem of the reporting justice's vote is the scope of the established thesis, according to which "the wrongful acts committed by foreign States in violation of human rights do not enjoy jurisdictional immunity". ${ }^{19}$ An example of such a broad scope in the States' practice is unknown. Even the decisions that repealed the immunity rule and could eventually have appeared in the Justice's vote specify that only "serious violations" of human rights could the rule of the immunity rule. Should such a decision prevail, Brazil would be moving beyond the progressive but controversial positions taken by the Greek and Italian courts and the recent South Korean decision, which tried to judicially remedy serious human rights violations in its territory carried out by Japan. ${ }^{20}$ Furthermore, considering the broad manner in which the thesis was framed, there is no distinction on which human rights would be able to ward off the rule of immunity. In this vein, one could wonder whether the sole violation of economic, social, cultural, and environmental rights, or even less obvious rights, such as the right to property, would result in the repeal of States' immunity.

The reaction of other States to a potential easing of jurisdictional immunity by the Brazilian judiciary would be equally interesting to verify. Reactions to sentenza 238/2014 of the Italian Constitutional Court, which assumed that the customary rule of immunity in the case of serious violations arises "in contrast to the fundamental principle of judicial protection of fundamental rights ensured by the Italian constitution", have been several. Should Brazilian Constitutional Court follow the same path, the strada can be full of resistances, either from international or national levels. In a legal framework governed by the logic of reciprocity, ${ }^{21}$ guaranteeing immunity is also making sure that your own immunity will be guaranteed. 19 Translation from Portuguese. From the original: “os atos ilícitos
praticados por Estados estrangeiros em violação a direitos humanos
não gozam de imunidade de jurisdição".
20 On the issue, see FRANCHINI, Daniel. South Korea's denial of
Japan's immunity for international crimes: Restricting or bypassing
the law of state immunity? Völkerrechtsblog, 18 Jan. 2021; and BRAN-
CA, Eleonora. 'Yet, it moves...': The Dynamic Evolution of State
immunity in the 'Comfort Women' case. EJIL: Talk!, 7 Apr. 2021.
21 On the issue, see SHAN, Wenhua; WANG, Peng. Divergent
Views on State Immunity in the International Community. In: RUY,
Tom; ANGELET, Nocolas; FERRO, Luca (eds.). The Cambridge
Handbook of Immunities and International Law. Cambridge: Cambridge
University Press, 2019. p. 61-78. 
There is no doubt that human rights violations require reparation; this is a fundamental principle of Brazilian, Inter-American, and international law. However, the risk of opening gaps in the immunity rule is not only to unleash Brazilian responsibility for violating international law but to create a precedent that transforms jurisdictional immunity, which "occupies an important place in international law and international relations" 22 , in a meaningless rule. Such rule derives directly from the sovereign equality of States, not only "one of the fundamental principles of the international legal order"23, but also recognized in Article 4 of the Brazilian Constitution. Thus, there is more to the Changri-la case than meets the eye. The STF decision might reverberate in national and international legal spheres in the years to come. It is not excluded, for instance, that the decision might end up at the Inter-American System of Human Rights or even in an interstate dispute with Germany. These are good reasons why the majority ruling should resonate with the soundest arguments at the international level and engage properly with the international rules in question. Otherwise, the Brazilian Supreme Court would be sending the wrong message with regard its relationship with international law.

\section{References}

ALEBEEK, Rosanne van; PAVONI, Riccardo. Immunities of States and their Officials. In: NOLLKAEMPER, André; REINISCH, August; JANIK, Ralph; SIMLINGER, Florentina (eds.). International Law in Domestic Courts: A Casebook. Oxford: Oxford University Press, 2018. p. 100-169.

AMOROSO, Daniele. Chapter 11 - Italy. In: PALOMBINO, Fulvio Maria (ed.). Duelling for Supremacy: International Law vs. National Fundamental Principles. Cambridge: Cambridge University Press, 2019. p. 184-209.

ARCARI, Maurizio; PALCHETTI, Paolo; TANCREDI, Antonello. Il giudice interno di fronte agli obblighi internazionali. Tra ondate identitarie e risacche di dédoublement fonctionnel. Quaderni costitu乏ionali, p. 217-224, Mar. 2020.

${ }^{22}$ ICJ. Jurisdictional Immunities of the State (Germany v. Italy: Greece intervening), Judgment, ICJ Reports 2012, para. 57.

23 ICJ. Jurisdictional Immunities of the State (Germany v. Italy: Greece intervening), Judgment, ICJ Reports 2012, para. 57.
BIANCHI, Andrea. Ferrini v. Federal Republic of Germany. The American Journal of International Law, v. 99, n. 1, p. 242-248, jan. 2005.

BORNKAMM, Christoph. State Immunity against Claims Arising from War Crimes: The Judgement of the International Court of Justice in Jurisdictional Immunities of the State. German Law Journal, v. 13, n. 6, 2012, p. 773-782.

BRANCA, Eleonora. 'Yet, it moves...': The Dynamic Evolution of State immunity in the 'Comfort Women' case. EJIL: Talk!, 7 Apr. 2021.

BRAZIL. Tribunal Marítimo. Processo $n^{\circ}$ 812/1943. Acórdão. B/P "CHANGRI-LÁ”. Naufrágio de barco de pesca, com a perda total da embarcação e a morte de dez tripulantes: José da Costa Marques, Deocleciano Pereira da Costa, Otávio Vicente Martins, Ildefonso Alves da Silva, Manoel Gonçalves Marques, Manoel Francisco dos Santos Júnior, Otávio Alcântara, Zacarias da Costa Marques, Apúlio Vieira de Aguiar e Joaquim Mata de Navarra. Oficiar à Diretoria de Portos e Costas e ao Serviço de Documentação da Marinha com o teor desta decisão, para as medidas competentes. Ataque pela artilharia do submarino alemão U-199, durante a $2^{a}$ Guerra Mundial. Judgement of 31 July 2001. Available at: https://tm-jurisprudencia.marinha.mil.br/solr/ anuarios/812.pdf.

DE SENA, Pasquale; DE VITTOR Francesca. State Immunity and Human Rights: the Italian Supreme Court Decision on the Ferrini Case. European Journal of International Law, v. 16, p. 89-112, 2005.

FONTANELLI, Filippo. Damage-assessment on the building of international law. Völkerrechtsblog, 15 Dec. 2014.

FRANCHINI, Daniel. South Korea's denial of Japan's immunity for international crimes: Restricting or bypassing the law of state immunity? Völkerrechtsblog, 18 Jan. 2021.

GARCIA, Márcio e MADRUGA FILHO, Antenor Pereira (coord.). A Imunidade de Jurisdição e o Judiciário Brasileiro. Brasília: CEDI, 2002.

ICJ. Jurisdictional Immunities of the State (Germany v. Italy: Greece intervening), Judgment, ICJ Reports 2012.

ILC. Draft Conclusions on Identification of Customary International Law, with Commentaries. Yearbook of the International Law Commission, v. II, part 2, 2018. 
KUNZ, Rafaella. Teaching the World Court Makes a Bad Case: Revisiting the Relationship Between Domestic Courts and the ICJ. In: VOLPE, Valentina; PETERS, Anne; BATTINI, Stefano (eds), Remedies against Immunity?, p. 259-280, Springer, 2021.

LIMA, Lucas Carlos. Regionalism in the codification of international law: the experience of the Inter-American Juridical Committee. In: ANNONI, Alessandra; FORLATI, Serena; SALERNO, Francesco. (org.). La codificazione nell'ordinamento internazionale e dell'Unione europea. Società Italiana di Diritto Internazionale (SIDI). Napoli: Editoriale Scientifica, 2019, p. 393-407.

MADRUGA FILHO, Antenor Pereira. A renúncia à imunidade de jurisdição pelo estado brasileiro e o novo direito da imunidade de jurisdição. Rio de Janeiro: Renovar, 2003.

MOLL, Leandro de Oliveira. Imunidades Internacionais: tribunais nacionais ante a realidade das organizações internacionais. 2. ed. Brasilia: FUNAG, 2011.

PETERS, Anne; VOLPE, Valentina. Introduction: In search for conciliation. VerfBlog, 11 May 2017.

SALIBA, Aziz Tuffi; MAIA, Tainá. Changri-lá, Antônio Apúlio Aguiar Coutinho and others v The Federal Republic of Germany, Reparation proceedings, Ordinary appeal judgment, No 2008/0042275-3, ILDC 1160 (BR 2008). In: NOLLKAEMPER, André; REINISCH, August. (org.). Oxford Reports on International Law in Domestic Courts. 2. ed.O xford: Oxford University Press, 2020.

PALCHETTI, Paolo. Italian concerns after sentenza 238/2014: possible reactions, possible solutions. Verfassungsblog. 11 Maio 2017.

PALCHETTI, Paolo. Judgment 238/2014 of the Italian Constitutional Court: In search of a way out. QILQuestions of international law, Zoom out II, 2014. p. 44-47.

SHAN, Wenhua; WANG, Peng. Divergent Views on State Immunity in the International Community. In: RUY, Tom; ANGELET, Nocolas; FERRO, Luca (eds.). The Cambridge Handbook of Immunities and International Law. Cambridge: Cambridge University Press, 2019. p. 61-78.

SOARES, Guido Fernando Silva. Órgãos dos Estados nas Relações Internacionais: Formas da Diplomacia e as Imunidades. Rio de Janeiro: Forense, 2001.

TAMS, Christian J. A Dangerous Last Line of Deference: Or, a Roman Court Goes Lutheran. In: VOLPE,
Valentina; PETERS, Anne; BATTINI, Stefano (eds.). Remedies against Immunity? Springer, 2021, pp. 237-258.

TIBURCIO, Carmen. Extensão e limites da jurisdição brasileira: competência internacional e imunidade de jurisdição. Salvador: JusPODIVM, 2019.

WÜRKERT, Felix. No custom restricting state immunity for grave breaches - well why not?. Völkerrechtsblog, 11 Dec. 2014 
Para publicar na Revista de Direito Internacional, acesse o endereço eletrônico www.rdi.uniceub.br ou www.brazilianjournal.org.

Observe as normas de publicação, para facilitar e agilizar o trabalho de edição. 